\title{
Vacatio legis ustawy o podatku od niektórych instytucji finansowych w kontekście zasady należytej legislacji
}

\section{Vacatio legis of the bill concerning bank levy imposed on certain financial institutions in the context of the principle of good legislation}

\begin{abstract}
Streszczenie. Opracowanie poświęcone zostało zbadaniu odpowiedniości 14-dniowego terminu vacatio legis ustawy z dnia 15 stycznia 2016 r. o podatku od niektórych instytucji finansowych, w szczególności w kontekście wpływu tego terminu na sprzedaż produktów bankowych, nadto próbie ustalenia, czy zastosowanie innego terminu przepisów dostosowawczych pozwoliłoby na uniknięcie lub ograniczenie ewentualnych negatywnych konsekwencji dla banków wynikających z wejścia w życie ww. ustawy. Opracowanie stanowi jednocześnie - na podstawie wyników przeprowadzonych badań - próbę odpowiedzi na pytanie, czy powyższy termin odpowiada konstytucyjnemu wymogowi przestrzegania zasady należytej legislacji.
\end{abstract}

Słowa kluczowe: zasada należytej legislacji; przepisy dostosowawcze; podatek bankowy. 


\begin{abstract}
The study is devoted to the examination of an adequacy of a 14-day long period of vacatio legis concerning the Bill of January 15, 2016 imposing a tax on certain financial institutions. The article if focused, in particular on the context of its impact on the sale of the bank products. It is also an attempt to determine whether any other period of adaptive regulations would allow to avoid or to limit possible negative consequences for banks, when the above mentioned regulations comes into force. The study also tries to answer the question whether the above period complies with the constitutional requirement of observing the principle of good legislation.
\end{abstract}

Keywords: principle of good legislation; adaptive regulations; a banking tax.

\title{
1. Wprowadzenie
}

Ustawą z dnia 15 stycznia 2016 r. o podatku od niektórych instytucji finansowych ${ }^{1}$ do polskiego systemu podatkowego został wprowadzony nowy podatek ${ }^{2}$. Jak wynika z uzasadnienia ustawy, celem ustawodawcy jest pozyskanie dodatkowego źródła finansowania wydatków budżetowych, a w szczególności rządowych wydatków społecznych ${ }^{3}$. Aby wyrównać obciążenia związane z podwyższeniem o jeden punkt procentowy podstawowej stawki podatku VAT nałożonej na społeczeństwo w wyniku nowelizacji ustawy o podatku od towarów i usług ${ }^{4}$, prawodawca uznał za zasadne obciążenie w podobnym stopniu

Dz.U. z 2016 r., poz. 68, dalej: u.p.n.i.f.

Dalej: podatek bankowy. Podatek bankowy jest konstrukcją współczesną, szerzej stosowaną po międzynarodowym kryzysie finansowym związanym z kredytami subprime. Ogólnie podatek ten można zdefiniować jako obciążenie publicznoprawne adresowane do określonej grupy podmiotów finansowych, najczęściej banków i niektórych parabanków. Zob. P. Dec, P. Masiukiewicz, Podatek bankowy, Warszawa 2013, s. 17.

3 Poselski projekt ustawy o podatku od niektórych instytucji finansowych, s. 1, http://www.sejm.gov.pl/Sejm8.nsf/druk.xsp?nr=75 (dostęp: 03.12.2017 r.), dalej: poselski projekt u.p.n.i.f.

4 Art. 19 ust. 5 ustawy z dnia 26 listopada 2010 r. o zmianie niektórych ustaw związanych z realizacją ustawy budżetowej (Dz.U. z 2010 r. Nr 238, poz. 1578) oraz art. 1 ust. 4 ustawy $\mathrm{z}$ dnia 8 listopada $2013 \mathrm{r}$. o zmianie ustawy o podatku od towarów i usług oraz niektórych innych ustaw (Dz.U. z 2013 r., poz. 1608). 
sektora finansowego, zwiększając jego udział w finansowaniu wydatków budżetowych.

Zgodnie z ustawą opodatkowaniem zostały objęte banki (krajowe, oddziały banków zagranicznych, oddziały instytucji kredytowych), zakłady ubezpieczeń i reasekuracji, spółdzielcze kasy oszczędnościowo-kredytowe oraz firmy pożyczkowe ${ }^{5}$. Wartość wolnych od podatku aktywów banków oraz spółdzielczych kas oszczędnościowo-kredytowych wynosi $4 \mathrm{mld} \mathrm{zł}^{6}$. W przypadku ubezpieczycieli są to $2 \mathrm{mld} \mathrm{zł}^{7}$, a w przypadku firm pożyczkowych - $200 \mathrm{mln} \mathrm{zl}^{8}$. Ustawa zakłada, że wartość aktywów, powyżej której instytucje finansowe będą płacić podatek, dotyczy nie pojedynczych podmiotów, ale całej grupy kapitałowej ${ }^{9}$. Ustawa zwalnia od podatku banki państwowe w rozumieniu ustawy z dnia 29 sierpnia 1997 r. - Prawo bankowe ${ }^{10}$.

Podatek bankowy został wprowadzony na wzór podatków obowiązujących w innych krajach członkowskich UE, m.in. w Wielkiej Brytanii, Portugalii, na Węgrzech, we Francji i w Szwecji, gdzie w zależności od przyjętej konstrukcji ma charakter antykryzysowy lub budżetowy i najczęściej stanowi procent sumy aktywów podmiotu zobowiązanego do zapłaty podatku. Stawki podatku są zróżnicowane w zależności od kraju, w którym podatek został wprowadzony, niemniej

\footnotetext{
Art. 4 u.p.n.i.f.

Art. 5 ust. 1 u.p.n.i.f.

Art. 5 ust. 2 u.p.n.i.f.

Art. 5 ust. 3 u.p.n.i.f.

Zgodnie z art. 5 ust. 3 u.p.n.i.f. wartość tę oblicza się łącznie dla wszystkich podatników zależnych lub współzależnych pośrednio lub bezpośrednio od jednego podmiotu lub grupy podmiotów powiązanych ze sobą. Założenie to ma służyć przeciwdziałaniu sztucznemu dzieleniu podmiotów w celu uniknięcia opodatkowania.

10 Art. 10 u.p.n.i.f. Zgodnie z art. 14 ust. 1 ustawy z dnia 29 sierpnia 1997 r. - Prawo bankowe (tekst jedn. Dz.U. z 2017 r., poz. 1876) bank państwowy może być utworzony przez Radę Ministrów w drodze rozporządzenia, na wniosek ministra właściwego do spraw Skarbu Państwa na podstawie art. 4 ust. 1, art. 5 pkt 19 i art. 25 ustawy z dnia 4 września 1997 r. o działach administracji rządowej (tekst jedn. Dz.U. z 2018 r., poz. 762) zaopiniowany przez Komisję Nadzoru Finansowego. W tym samym trybie następuje likwidacja banku państwowego - z wyjątkiem przypadku, o którym mowa w art. 147 ust. 1 pkt 3.
} 
stawka podatkowa nie przekracza $0,1 \%$ przedmiotu opodatkowania ${ }^{11}$. Jak wyżej wspomniano, podatek bankowy jest nowym obciążeniem, z którego wpływy do budżetu w 2016 r. były planowane w kwocie 6,6-7 mld zł, natomiast rzeczywisty wpływ wyniósł ponad 3 mld $\mathrm{zł}^{12}$.

W związku z wprowadzeniem do systemu podatkowego nowego obciążenia krytyce zostało poddane zjawisko przerzucenia obciążenia na klientów. Zdaniem ustawodawcy zjawisko przerzucalności podatków wiąże się z podatkami pośrednimi, tj. podatkiem od towarów i usług oraz akcyzą. Nie do końca można się z tym zgodzić, bowiem jest to tylko pozorne przerzucenie podatku ${ }^{13}$, polegające na opodatkowaniu konsumenta i zaangażowaniu innego podmiotu do jego poboru, tj. producenta lub sprzedawcy ${ }^{14}$, natomiast rzeczywiste przerzucenie podatków występuje wówczas, gdy podatnik zobowiązany z mocy prawa do zapłacenia podatku $\mathrm{z}$ własnego dochodu i majątku przenosi jego ciężar na inny podmiot. W ocenie prawodawcy zagrożeni zjawiskiem przerzucalności mogą być jedynie kredytobiorcy, z uwagi na możliwość wzrostu marży banków oferujących kredyty ${ }^{15}$. W przypadku kredytobiorców zjawisko to może przybrać postać przerzucania podatku w przód, tzn. ciężar części lub całości opodatkowania przenosi się z producenta na konsumentów w mechanizmie podnoszenia cen, po to aby zminimalizować lub zniwelować nałożony podatek ${ }^{16}$. Z analizy rynku przeprowadzonej przez Komisję Nadzoru Finansowego wynika, że konsekwencją wprowadzenia podatku bankowego było obniżenie oprocentowania części depozytów, wzrost

11 M. Marcinkowska, Dodatkowe opłaty i podatki od banków - potrzeby praktyki i dylematy teorii finansów, s. 14, http://kbd.projektekf.pl/sites/default/files/materialy_prasowe/ podatek\%20bankowy_Marcinkowska.pdf (dostęp: 17.08.2017 r.).

12 Komisja Nadzoru Finansowego, Departament Bankowości Komercyjnej i Specjalistycznej oraz Instytucji Płatniczych, Syntetyczna informacja na temat wpływu podatku od niektórych instytucji finansowych na sytuację banków komercyjnych, Urząd Komisji Nadzoru Finansowego, Warszawa, sierpień 2017, s. 4, https://www.knf.gov.pl/ knf/pl/komponenty/img/Opracowanie_podatek_bankowy_17-08-2017_58323.pdf (dostęp: 17.08.2017 r.).

A. Gomułowicz, D. Mączyński, Podatki i prawo podatkowe, Warszawa 2016, s. 390.

Tamże.

Poselski projekt u.p.n.i.f., s. 6 i 7.

A. Gomułowicz, D. Mączyński, Podatki..., s. 391. 
marż części kredytów, a także wzrost opłat i prowizji od niektórych usług $^{17}$.

Oprócz powyższego zjawiska krytyce poddany został 14-dniowy termin vacatio legis ustawy. O ile pierwszy problem został zweryfikowany m.in. badaniami Komisji Nadzoru Finansowego, to drugi stanowi jedynie twierdzenie niezweryfikowane empirycznie. Zbadanie omawianego problemu ma na celu w szczególności próbę wyjaśnienia, czy pomiędzy wzrostem cen produktów finansowych i spadkiem oprocentowania depozytów a 14-dniowym terminem vacatio legis zachodzi zależność, a jeżeli tak, to czy wprowadzenie innego terminu przepisów dostosowawczych pozwoliłoby na uniknięcie lub ograniczenie wzrostu cen produktów sprzedażowych oraz uniknięcie lub ograniczenie innych problemów praktycznych w dostosowywaniu działalności instytucji do nowej rzeczywistości prawnej.

W konsekwencji intencją autora jest również próba wyjaśnienia, czy powyższy termin odpowiada konstytucyjnemu wymogowi przestrzegania reguł przyzwoitej legislacji.

\section{Doktrynalna klasyfikacja podatku bankowego}

W doktrynie prawa finansowego za najpowszechniejszy przyjmuje się podział podatków ze względu na przedmiot obciążenia ${ }^{18}$. Dzieląc podatki według przedmiotu opodatkowania, wyróżniamy podatki: przychodowe, dochodowe, majątkowe i od wydatków. Przedmiotem podatków przychodowych jest uzyskiwany przychód, co oznacza, że są one pobierane wówczas, gdy powstają odpowiednie przychody z poszczególnych źródeł ${ }^{19}$. Wśród podatków przychodowych wyróżnia się podatki dochodowe, tj. takie, które obciążają przychód pomniejszony o koszty poniesione $\mathrm{w}$ celu uzyskania lub maksymalizacji dochodu ${ }^{20}$.

17 A. Kotowicz, Komisja Nadzoru Finansowego. Departament Bankowości Komercyjnej i Specjalistycznej oraz Instytucji Płatniczych, Raport o sytuacji banków w 2016 r., Urząd Komisji Nadzoru Finansowego, Warszawa 2017, s. 42, https://www.knf.gov.pl/knf/pl/komponenty/img/RAPORT_O_SYTUACJI_BANKOW _2016_54435.pdf (dostęp: 30.11.2017 r.). 
Natomiast przedmiot podatków konsumpcyjnych związany jest ze sposobem zużywania dochodów lub zasobów majątkowych, a opodatkowanie konsumpcji dokonuje się w momencie ponoszenia wydatku $^{21}$. Z kolei podatek, którego przedmiot i podstawa opodatkowania związane są z majątkiem, określany jest jako podatek majątkowy ${ }^{22}$.

Z uzasadnienia ustawy wynika, że przedmiotem opodatkowania jest suma wartości aktywów podatnika wynikająca z zestawienia obrotów i sald ${ }^{23}$, co klasyfikuje podatek bankowy jako podatek majątkowy ${ }^{24}$. W przypadku podatku majątkowego za przedmiot i podstawę opodatkowania przyjmuje się majątek. Podatki majątkowe przybierają postać podatków nominalnych lub realnych ${ }^{25}$. Podatek realny charakteryzuje uszczuplenie majątku ${ }^{26}$, natomiast źródłem podatku nominalnego jest dochód $\mathrm{z}$ majątku ${ }^{27}$. Podobnie rzecz ujmuje się w nauce prawa podatkowego, wskazując, że jeżeli podatki płacone są z dochodu, jaki przynosi rzecz, to mają charakter podatków nominalnych, natomiast

18 A. Gomułowicz, D. Mączyński, Podatki..., s. 161.

19 Rozbudowa podatków przychodowych i ich dominacja w systemie podatkowym z reguły świadczą o niskim poziomie rozwoju gospodarczego państwa. A. Gomułowicz, D. Mączyński, Podatki..., s. 162.

20 Tworzenie dochodu (zysku) podlegającego następnie opodatkowaniu jest możliwe tylko przy wysokim poziomie rozwoju gospodarczego. Tamże, s. 163.

21 Z uwagi na to, że konsumpcja dotyczy praktycznie wszystkich dóbr i usług, opodatkowanie konsumpcji jest jedną $\mathrm{z}$ najbardziej powszechnych form opodatkowania. Tamże, s. 165.

22 Podatki majątkowe mogą obciążać zarówno majątek ludności, jak i majątek podmiotów gospodarczych (kryterium podmiotu opodatkowania). Można wyróżnić także podatki majątkowe, które obciążają: posiadanie majątku, nabycie lub zbycie majątku, przyrost majątku. Ponadto zakresem opodatkowania można objąć całość majątku albo poszczególne składniki majątku. Tamże, s. 164.

23 Przy czym podstawę opodatkowania obniża się o wartość funduszy własnych otrzymanych przez podatników prowadzących działalność kredytowo-pożyczkową ze względu na konieczność ochrony ich interesów jako depozytariuszy. Poselski projekt u.p.n.i.f., s. 6. Podatki bankowe i kapitałowe są zaliczane do tzw. podatków majątkowych. P. Dec, P. Masiukiewicz, Podatek..., s. 17.

25 R. Wolański, System podatkowy w Polsce, Warszawa 2016, s. 43.

26 Koszt podatków realnych, który ponoszony jest bezpośrednio z majątku, obniża jego wartość, np. podatek od spadków i darowizn. Tamże.

27 Podatki majątkowe nominalne opodatkowują majątek, ale ponoszone są z dochodu, który ten majątek przynosi, np. podatek od nieruchomości wykorzystywanej na wynajem lub prowadzenie działalności gospodarczej. Tamże. 
jeżeli źródłem, z którego są płacone podatki, pozostaje majątek, to są to podatki majątkowe realne ${ }^{28}$.

Pojęcie majątku nie doczekało się definicji ustawowej. W znaczeniu szerokim rozumiane jest ono jako ogół aktywów i pasywów należących do określonego podmiotu, natomiast w znaczeniu wąskim - jako masa majątkowa obejmująca wyłącznie aktywa; pasywa w tym znaczeniu nie wchodzą w skład majątku, lecz obniżają jego wartość ekonomiczną ${ }^{29}$. W przedstawionym ujęciu majątku pasywa traktowane są jako środki jego pochodzenia, a ich zestawienie $\mathrm{z}$ aktywami określa się mianem bilansu ${ }^{30}$.

W rozumieniu kodeksowym majątek ujęty jest jako mienie. Zgodnie z definicją legalną mieniem jest własność i inne prawa majątkowe ${ }^{31}$. Mienie oznacza wyłącznie aktywa, jest zatem ujęte wąsko. Tezę tę można wyprowadzić z twierdzenia, zgodnie z którym pozostawienie poza zakresem pojęcia przedsiębiorstwa zobowiązań związanych $\mathrm{z}$ jego prowadzeniem stanowi konsekwencję nawiązania przez polskiego ustawodawcę do wąskiego ujęcia mienia, obejmującego wyłącznie aktywa $^{32}$, co oznacza, że mieniem są tylko prawa, nie są zaś obowiązki (długi), które własność i inne prawa majątkowe tylko obciążają. Jak już wspomniano, pojęciem mienia $\mathrm{w}$ znaczeniu wąskim są zatem objęte jedynie aktywa przysługujące określonemu podmiotowi, w znaczeniu szerokim zaś majątek to ogół aktywów i obciążające te aktywa długi. Zatem tylko definicja sensu stricto majątku i pojęcie kodeksowe mogą być używane zamiennie jako synonimy ${ }^{33}$.

28 A. Gomułowicz, D. Mączyński, Podatki..., s. 166.

29 W ujęciu ustawowym przez aktywa należy rozumieć kontrolowane przez jednostkę zasoby majątkowe o wiarygodnie określonej wartości powstałe w wyniku przeszłych zdarzeń, które spowodują w przyszłości wpływ do jednostki korzyści ekonomicznych (art. 3 ust. 1 pkt 12 ustawy z dnia 29 września 1994 r. o rachunkowości (tekst jedn. Dz.U. z 2018 r., poz. 395 ze zm.).

L. Etel, G. Liszewski, Podatki majatkowe w Polsce - wybrane problemy, Kancelaria Sejmu. Biuro Studiów i Ekspertyz. Wydział Studiów Budżetowych, raport nr 209, wrzesień 2002, s. 5.

31 Art. 44 ustawy z dnia 23 kwietnia 1964 r. - Kodeks cywilny (tekst jedn. Dz.U. z 2018 r., poz. 1025 ze zm., dalej: k.c.).

32 Tak Sąd Najwyższy w wyroku z dnia 3 grudnia 2009 r., II CSK 215/09, LEX nr 551060.

33 Pojęcie „majątek” na gruncie przepisów kodeksu cywilnego jest bliskie pojęciu mienia, zdefiniowanemu w art. 44 k.c. Brak konsekwencji ustawodawcy uwidacznia się 
W ujęciu doktrynalnym nie mniej ważnym podziałem jest podział na podatki o otwartym stanie faktycznym oraz o zamkniętym stanie faktycznym. Otwarte stany faktyczne dotyczą zdarzeń lub działań, jakie następują w pewnym przedziale czasowym, tj. przez pewien okres, w którym można z danym podmiotem wiązać sytuacje faktyczne lub prawne, z którymi łączy się obowiązek podatkowy. Obowiązek podatkowy powstaje z początkiem danego okresu i zostaje przekształcony w zobowiązanie podatkowe po upływie tego okresu ${ }^{34}$. Otwarty stan faktyczny to zdarzenia lub działania, jakie mają miejsce w pewnym przedziale czasowym, gdy istniejący stan faktyczny nie jest jeszcze stanem zamkniętym, a jego urzeczywistnianie rozpoczęło się przed wydaniem nowych przepisów, ale jeszcze nie zostało zakończone (np. zmiana stawek podatkowych $\mathrm{w}$ podatku dochodowym $\mathrm{w}$ trakcie roku podatkowego) ${ }^{35}$.

Zamknięty stan faktyczny charakteryzuje to, że obowiązek podatkowy i zobowiązanie podatkowe powstają równocześnie ${ }^{36}$. Na przykładzie podatku od towaru i usług można wskazać, że zasadą ${ }^{37}$ jest jednoczesne powstanie obowiązku i zobowiązania w stosunku do każdej transakcji, a przede wszystkim oparcie konstrukcji tego podatku na mechanizmie opodatkowania i obliczania, determinującym wybór techniki postępowania podatkowego ${ }^{38}$. Takie właśnie ukształtowanie powstania obowiązku podatkowego wynika z tego, że w przypadku podatku od towarów i usług czynność prawna rodząca obowiązek podatkowy ma

w określeniu majątku spadkowego w rozumieniu art. 922 k.c., który określa spadek jako ogół praw i obowiązków majątkowych zmarłego, czyli posługuje się definicją majątku sensu largo. Podobnie za takim rozumieniem majątku mogłaby przemawiać wykładnia przepisów ustawy z dnia 25 lutego 1964 r. - Kodeks rodzinny i opiekuńczy (tekst jedn. Dz.U. z 2017 r. poz. 682 ze zm.) dotyczących zarządu majątkiem wspólnym małżonków.

R. Mastalski, Stosowanie prawa podatkowego, Warszawa 2008, s. 139.

Tamże, s. 174.

36 M. Kwietko-Bębnowski, Ordynacja podatkowa. 366 wyjaśnień i interpretacji, Warszawa 2013, s. 268-269.

37 Zgodnie z art. 19a ustawy o podatku od towarów i usług obowiązek podatkowy powstaje z chwilą dokonania dostawy towarów lub wykonania usługi, z zastrzeżeniem ust. 5 i 7-11, art. 14 ust. 6 , art. 20 i art. 21 ust. 1.

R. Mastalski, Tworzenie prawa podatkowego a jego stosowanie, Warszawa 2016, s. 120. 
samoistny charakter tworzący zamknięty stan faktyczny podlegający opodatkowaniu ${ }^{39}$.

Z uwagi na fakt, że podatnicy są obowiązani, bez wezwania ze strony właściwego organu podatkowego, do obliczania i wpłacania podatku na rachunek właściwego urzędu skarbowego - za miesięczne okresy rozliczeniowe w terminie do 25. dnia miesiąca następującego po miesiącu, którego podatek dotyczy, podatek ten można zakwalifikować jako podatek o zamkniętym stanie faktycznym ${ }^{40}$.

\section{Konstytucyjne uwarunkowania vacatio legis ustaw podatkowych}

Termin vacatio legis (łac. vacatio - zwolnienie, lex, legis - prawo) oznacza określony przedział czasowy między ogłoszeniem aktu normatywnego a jego wejściem w życie. Wymóg ustanowienia odpowiedniego okresu vacatio legis oraz należytego formułowania przepisów dostosowawczych wywodzi się z ogólnej zasady ochrony zaufania obywatela do państwa i stanowionego przez nie prawa oraz zasady przyzwoitej legislacji, a także stanowi element koncepcji państwa prawnego wyrażonej $\mathrm{w}$ art. 2 Konstytucji ${ }^{41}$. Celem vacatio legis jest stworzenie możliwości zapoznania się z treścią aktu normatywnego, zanim zacznie on obowiązywać.

Przepis art. 2 Konstytucji formułuje zasadę, zgodnie z którą Rzeczpospolita Polska jest demokratycznym państwem prawnym, urzeczywistniającym zasady sprawiedliwości społecznej. Zasada demokratycznego państwa prawnego to zbiorczy wyraz wielu zasad i reguł, które nie są wprost ujęte w Konstytucji, ale w sposób immanentny wynikają z aksjologii oraz z istoty demokratycznego państwa prawnego.

\footnotetext{
E. Fojcik-Mastalska, R. Mastalski, Prawo finansowe, Warszawa 2013, s. 325-326.

Art. 8. ust. 1 pkt 2 u.p.n.i.f.

41 Konstytucja Rzeczypospolitej Polskiej (Dz.U. z 1997 r. Nr 78, poz. 483 ze zm.); M. Grabowski, Odpowiedź podsekretarza stanu w Ministerstwie Finansów - z upoważnienia ministra - na interpelację nr 19682, http://orka2.sejm.gov.pl/IZ6.nsf/main/62C50989 (dostęp: 30.11.2017 r.).
} 
Wyprowadzona z niej została zasada ochrony zaufania obywatela do państwa i stanowionego przez nie prawa i wynikający z niej obowiązek zapewnienia bezpieczeństwa prawnego oraz szereg innych zasad, m.in. ochrony praw nabytych i interesów w toku, zakaz wstecznego działania prawa, nakaz przestrzegania reguł przyzwoitej legislacji, w tym przestrzegania zasady dostatecznej określoności przepisów prawa oraz ustanawiania odpowiedniego vacatio legis ${ }^{42}$.

Przytaczając stanowisko doktryny, należy wskazać, że zachowanie odpowiedniego vacatio legis sprzyja osiągnięciu stanu pewności prawnej i bezpieczeństwa obywateli, stanowiących istotę zasady zaufania obywateli, o której mowa powyżej ${ }^{43}$. Zasada ochrony zaufania obywatela do państwa opiera się na pewności prawa, a więc na takim zespole cech przysługujących prawu, które zapewniają jednostce bezpieczeństwo prawne, umożliwiają jej decydowanie o własnym postępowaniu na podstawie pełnej znajomości przesłanek działania organów państwowych $^{44}$.

Minimalny okres vacatio legis został wprowadzony ustawą z dnia 20 lipca 2000 r. o ogłaszaniu aktów normatywnych i niektórych innych aktów prawnych ${ }^{45}$. Zgodnie z art. 4 ust. 1 u.o.a.n. akty normatywne, zawierające przepisy powszechnie obowiązujące, ogłaszane w dziennikach urzędowych wchodzą w życie po upływie 14 dni od dnia ich ogłoszenia, chyba że dany akt normatywny określi termin dłuższy. Wyznaczony przez komentowany przepis 14-dniowy okres vacatio legis jest uznawany $\mathrm{w}$ orzecznictwie za „minimalny standard"46. Zasadą nadrzędną jest jednak zasada „odpowiedniości” okresu vacatio legis, co oznacza, że w konkretnym przypadku może istnieć potrzeba ustanowienia

42 Biuro Trybunału Konstytucyjnego, Proces prawotwórczy w świetle orzecznictwa Trybunału Konstytucyjnego. Wypowiedzi Trybunału Konstytucyjnego dotyczqce zagadnień zwiqzanych z procesem legislacyjnym, Warszawa 2015, s. 7.

43 J. Jaskiernia, Zasady demokratycznego państwa prawnego w sejmowym postępowaniu ustawodawczym, Warszawa 1999, s. 316.

44 Wyrok TK z dnia 25 czerwca 2002 r., K 45/01, LEX nr 54906.

45 Tekst jedn. Dz.U. z 2017 r., poz. 1523, dalej u.o.a.n.

46 Wyrok TK z dnia 10 grudnia 2002 r., K 27/02, LEX nr 57101. 
znacznie dłuższego okresu spoczywania aktu ${ }^{47}$. Odpowiedniość vacatio legis trzeba rozpatrywać w związku z możliwością pokierowania - po ogłoszeniu nowych przepisów - swoimi sprawami w sposób uwzględniający treść nowej regulacji. Wymóg zachowania vacatio legis należy bowiem odnosić nie tylko do ochrony adresata normy prawnej przed pogorszeniem jego sytuacji, lecz także do możliwości zapoznania się z nowym prawem i możliwości adaptacyjnych ${ }^{48}$. Ocena, czy w konkretnym przypadku długość okresu vacatio legis jest odpowiednia, zależy od całokształtu okoliczności, w szczególności zaś od przedmiotu i treści unormowań przewidzianych w nowych przepisach, w tym i od tego, jak dalece różnią się one od unormowań dotychczasowych ${ }^{49}$. Z drugiej strony Trybunał Konstytucyjny wskazał, że nakaz odpowiedniego vacatio legis nie ma charakteru bezwzględnego, co oznacza, że ustawodawca może zrezygnować z vacatio legis, jeżeli przemawia za tym ważny interes publiczny, którego nie można zrównoważyć interesem jednostki ${ }^{50}$.

Podobne stanowisko prezentuje doktryna prawa, wskazując, że odpowiedniość terminu 14-dniowego podlega ocenie osobno dla każdego uregulowania. W związku z tym odpowiedni może być okres przekraczający dwa tygodnie, a w określonych sytuacjach nawet trzymiesięczny okres vacatio legis może być uznany za naruszający Konstytucję. Badanie konstytucyjności musi zatem zawsze polegać na materialnym określeniu odpowiedniości terminu $\mathrm{w}$ stosunku do treści i charakteru nowych przepisów. Wymóg wprowadzenia odpowiedniego terminu może wynikać z niemożności dostosowania się adresata przepisu do skutków danej normy prawnej. W przypadku powiązania działalności gospodarczej i obowiązków podatkowych wobec państwa konieczność zapewnienia podatnikowi odpowiedniego planowania działalności jest szczególnie ważna ${ }^{51}$.

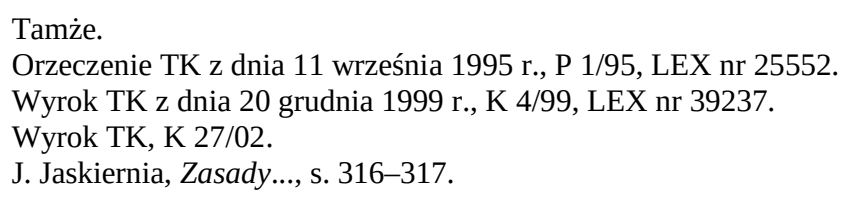


Również w orzecznictwie Trybunału Konstytucyjnego wyraźnie zarysował się pogląd, zgodnie z którym pewność przepisów prawa $\mathrm{w}$ zakresie danin publicznych ma ścisły związek $\mathrm{z}$ prowadzeniem działalności gospodarczej lub aktywnością zawodową podmiotów, które obowiązane są do płacenia tych danin ${ }^{52}$. Podmiotom tym pewność prawa zapewnia możliwość odpowiedniego planowania działalności. W ten sposób pewność prawa może sprzyjać rozwojowi gospodarczemu i aktywności zawodowej społeczeństwa w ogóle ${ }^{53}$. W ocenie Trybunału Konstytucyjnego $\mathrm{z}$ takiego rozumienia pewności prawa w dziedzinie danin publicznych wynika, że zmiana prawa powinna być dokonywana w ten sposób, by podmioty prawa, których ona dotyczy, miały odpowiedni czas do rozporządzenia swoimi interesami, czyli poprzez wyznaczenie pewnego horyzontu czasowego dla zaplanowania i przeprowadzenia przez podatnika określonego przedsięwzięcia finansowego czy gospodarczego ${ }^{54}$. Za sprzeczne ze standardem konstytucyjnym powinno się zatem uznać przepisy wprowadzane zbyt pośpiesznie, tj. takie, na których podstawie nie można przewidzieć, jak dana ustawa będzie działała w przyszłości, jak również na których podstawie nie jest możliwe planowanie swojej aktywności gospodarczej lub zawodowej. W ocenie Trybunału Konstytucyjnego nie spełnia wymogu stabilności prawa nagły sposób zmiany ustawy, bez przepisów dostosowawczych, przy nierespektowaniu interesów obywateli ${ }^{55}$.

Klauzula demokratycznego państwa prawnego i wynikająca z niej zasada zaufania obywatela do państwa nakładają na ustawodawcę obowiązek takiego wprowadzania nowych przepisów podatkowych, które szanuje tzw. interesy w toku, tj. przedsięwzięcia gospodarcze i finansowe rozpoczęte pod rządami przepisów poprzednich. Obowiązek uwzględnienia interesów w toku może być oczywiście relatywizowany z powołaniem się na ogólny argument ryzyka gospodarczego, które

\footnotetext{
Orzeczenie TK z dnia 2 marca 1993 r., K 9/92, LEX nr 25136.

Tamże.

Wyrok TK z dnia 27 lutego 2002 r., K 47/01, LEX nr 52925.

Orzeczenie TK z dnia 14 grudnia 1993 r., K 8/93, LEX nr 25424.
} 
odnosi się także do zmian stanu prawnego ${ }^{56}$. Należy zadać sobie natomiast pytanie, jak powinno się rozumieć klauzulę demokratycznego państwa prawa w odniesieniu do podatków o zamkniętym prawnopodatkowym stanie faktycznym.

Zgodnie $\mathrm{z}$ poglądem utrwalonym $\mathrm{w}$ orzecznictwie nie można dokonywać zmian prawa podatkowego w toku roku podatkowego co do podatków pobieranych w skali rocznej, niemniej nie jest to bezwzględny zakaz, lecz zakaz dotyczący zmian niekorzystnych dla podatnika. Zmiany prawa podatkowego $\mathrm{w}$ trakcie roku podatkowego pozostają w sprzeczności z konstytucyjną zasadą państwa prawnego, gdyż naruszają pewność prawa i zaufanie obywateli do państwa. Skoro zatem prawodawca nie może $\mathrm{w}$ ciągu roku podatkowego, a więc w czasie trwania prawnopodatkowego stanu faktycznego, derogować normy prawnej i wprowadzić w jej miejsce normy mniej korzystnej dla podatnika, to tym bardziej nie można derogować takiej normy w sposób dorozumiany w drodze usuwania kolizji norm na podstawie zasady następstwa czasowego - reguły lex posterior. Odmiennie to zagadnienie wygląda w przypadku podatków o zamkniętym prawnopodatkowym stanie faktycznym. W tego typu podatkach stan faktyczny występujący u danego podatnika rodzi nie tylko obowiązek podatkowy, lecz równocześnie z nim zobowiązanie podatkowe. Występuje tu zatem równoczesne otwarcie i zamknięcie prawnopodatkowego stanu faktycznego. W przypadku najbardziej powszechnego podatku, tj. podatku od towarów i usług, technika ustalania i poboru należności podatkowych prowadzi do tego, że podatek ten pobierany jest okresowo (miesięcznie, kwartalnie), a nie przy każdym akcie obrotu, jak to się dzieje w przypadku podatku obrotowego od przenoszenia praw majątkowych. Zatem podatnik powinien być chroniony od niekorzystnych dla niego zmian norm podatkowych przez cały okres rozliczeniowy. Wniosek ten wynika z zasady państwa prawnego oraz wyprowadzonej z niej przez Trybunał

56 Informacja przedstawiona Sejmowi Rzeczypospolitej Polskiej przez Prezesa Trybunału Konstytucyjnego na 50 posiedzeniu Sejmu RP 3 lipca 1998 r., http://trybunal.gov.pl/ publikacje/informacje-o-problemach-wynikajacych-z-dzialalnosci-i-orzecznictwa-tk/1997 (dostęp: 23.03.2018 r.). 
Konstytucyjny zasady pewności prawa oraz zasady zaufania do państwa i tworzonego przez nie prawa. Realizacja omawianych zasad konstytucyjnych wymaga przede wszystkim odpowiedniego vacatio legis, tak aby podatnik mógł się dostosować (chodzi zwłaszcza o działalność gospodarczą) do nowych rozwiązań prawnych. W odniesieniu do podatków o zamkniętym stanie faktycznym można dokonywać ich zmian w danym roku kalendarzowym, gdyż nie ma to wpływu na kształt tego stanu, lecz każda zmiana powinna uwzględniać interesy prawne podatników, zwłaszcza zaś możliwość dostosowania się do nowych, mniej korzystnych zasad opodatkowania ${ }^{57}$.

Udzielenia odpowiedzi wymaga również pytanie o termin wejścia w życie zupełnie nowych podatków. Inspiracją do poszukiwania odpowiedzi na postawione pytanie może być dorobek orzeczniczy Trybunału Konstytucyjnego, a szczególności wyrok z dnia 18 listopada 2014 r., K 23/12 $2^{58}$. Rozpatrywana sprawa dotyczyła m.in. konstytucyjności vacatio legis ustawy z dnia 2 marca 2012 r. o podatku od wydobycia niektórych kopalin (dalej: u.p.w.n.k.) ${ }^{59}$. Omawiana danina, podobnie jak podatek bankowy, powinna być obliczana i wpłacana na rachunek właściwej izby celnej za miesięczne okresy rozliczeniowe, $w$ terminie do 25 . dnia miesiąca następującego po miesiącu, w którym powstał obowiązek podatkowy ${ }^{60}$, zatem należy ją sklasyfikować jako podatek o zamkniętym stanie faktycznym. W omawianej sprawie zdaniem wnioskodawcy kwestionowane unormowanie narusza zasadę państwa prawnego w aspekcie jawności prawa przez ustanowienie zbyt krótkiego vacatio legis, bowiem podatnik powinien mieć nie tylko formalną, ale również rzeczywistą możliwość zapoznania się z treścią obowiązującego prawa, a w przypadku konieczności zapewnienia odpowiednich warunków koniecznych do pomiaru zawartości miedzi i srebra w urobku 14-dniowy termin jest zbyt krótki na przygotowanie się do wejścia w życie ustawy. Sporządzanie bowiem deklaracji podatkowych oraz obliczanie podatku od miedzi i srebra wymaga

\footnotetext{
R. Mastalski, Stosowanie..., s. 140-141.

Wyrok TK z dnia 18 listopada 2014 r., K 23/12, LEX nr 1548281.

Dz. U. poz. 362 oraz z 2014 r. poz. 1215.

Art. 14 ust. 1 pkt 2 u.p.w.n.k.
} 
posiadania odpowiednio przeszkolonego personelu i komputerowych programów obliczeniowych, a tym samym osiągnięcie tego stanu w ciągu 14 dni jest niemożliwe. Trybunał Konstytucyjny w odniesieniu do odpowiedniego vacatio legis $\mathrm{w}$ podatku od kopalin uznał przede wszystkim, że przewidziany w art. 27 u.p.w.n.k. okres odroczenia odpowiada generalnym założeniom z art. 4 ust. 1 u.o.a.n. Niemniej paradoksalnie, co nie jest oderwanym przypadkiem w praktyce Trybunału, wskazał on na konstytucyjność kwestionowanych przepisów ustawy z dnia 2 marca 2012 r. o podatku od wydobycia niektórych kopalin ${ }^{61}$, w tym przewidujących vacatio legis, i jednocześnie podał w wątpliwość „odpowiedniość” vacatio legis ze względu na wprowadzenie nowych obciążeń podatkowych w tak krótkim czasie, co mogło skutkować trudnościami w przygotowaniu się do ich poniesienia przez podatnika. Innymi słowy Trybunał zaznaczył, że wyznaczony przez ustawodawcę tak krótki okres spoczywania kwestionowanej ustawy nie stanowi optymalnego rozwiązania z punktu widzenia wymogów konstytucyjnych, niemniej jednak wada ta została zrównoważona przez doniosłość funkcji fiskalnej realizowanej ustawą o podatku ${ }^{62}$.

\section{Praktyczne skutki wprowadzenia \\ 14-dniowego terminu przepisów dostosowawczych podatku bankowego}

W przestrzeni publicznej został sformułowany zarzut, z którego wynika, że termin przepisów dostosowawczych omawianej ustawy o podatku

$61 \quad$ Tekst jedn. Dz.U. z 2018 r., poz. 228.

62 Jak wynika z komunikatu prasowego Trybunału Konstytucyjnego, na osłabienie argumentu dotyczącego zbyt krótkiego okresu vacatio legis wpływ ma to, że zapowiedź wprowadzenia podatku od niektórych kopalin pojawiła się już 18 listopada $2011 \mathrm{r}$. w exposé Prezesa Rady Ministrów, a sam projekt ustawy o podatku od kopalin wpłynął do Sejmu 19 stycznia 2012 r. i był przedmiotem procedowania przez niemal trzy miesiące. Tym samym adresaci unormowania mieli możliwość zapoznania się z projektowanymi rozwiązaniami wcześniej niż w momencie opublikowania ustawy w Dzienniku Ustaw, a przez to adaptacji do nowej regulacji prawnej mimo krótkiego, 14-dniowego okresu vacatio legis, http://trybunal.gov.pl/rozprawy/komunikatyprasowe/komunikaty-po/art/7238-zasady-nalezytej-legislacji/ (dostęp: 21.03.2018 r.). 
bankowym mógł być nieodpowiedni. W ocenie Konfederacji Lewiatan proponowana data wejścia $\mathrm{w}$ życie art. 13 projektowanej ustawy, tj. 1 lutego 2016 r., może budzić wątpliwości natury konstytucyjnej ${ }^{63}$. Ta i podobne wypowiedzi nie zostały poparte jednak żadną konkretną, a przede wszystkim praktyczną argumentacją, jak stało się to w przypadku omawianego wcześniej podatku od kopalin, który stanowi porównywalny model badawczy.

W literaturze ani orzecznictwie nie rozwinięto tezy, z której wynika nieodpowiedniość przepisów dostosowawczych ustawy o podatku bankowym. Podkreślenia wymaga fakt, że poza zakresem opracowania pozostaje ocena innych zarzutów braku konstytucyjności pozostałych przepisów ustawy o podatku bankowym.

W celu konfirmacji lub falsyfikacji przytoczonej tezy należy przede wszystkim przeanalizować postęp prac legislacyjnych nad ustawą, co pozwoli na sformułowanie odpowiedzi, z której będzie wynikać, czy podatnicy mieli możliwość zapoznania się z regulacją wprowadzoną przez ustawę i odpowiedniego zaplanowania swojej działalności.

Poselski projekt ustawy o podatku od niektórych instytucji finansowych wpłynął do Sejmu 3 grudnia 2015 r. ${ }^{64}$ Po publikacji projektu pojawiło się do niego szereg opinii podmiotów zainteresowanych ${ }^{65}$. Szczegółowa analiza przedłożonych opinii prowadzi do wniosku, że uwagi dotyczące tego projektu tylko w jednym przypadku dotyczyły możliwości naruszenia przez ustawodawcę zasady prawidłowej legislacji, jednak nie w zakresie przepisów dostosowawczych, a w zakresie budowy innych przepisów prawnych oraz konstrukcji samego podatku. Uwagi zawarte w opinii Business Center Club - wyłącznie natury ogólnej - sprowadzały się do wskazania wymogów koniecznych stawianych przepisom oraz kon-

63 Stanowisko Konfederacji Lewiatan do projektu ustawy o podatku od niektórych instytucji finansowych, https://bs.net.pl/ciekawe-rzeczy-w-sieci/lewiatan-o-podatku-bankowym (dostęp: 28.12.2015 r.).

65 Opinie BAS i ZBP z dnia 10 grudnia 2015 r.; opinia KZBS z dnia 14 grudnia 2015 r.; opinia NBP z dnia 17 grudnia 2015 r.; opinia PIU z dnia 18grudnia 2015 r.; opinie BCC, SN i UOKiK z dnia 21 grudnia 2015 r.; opinia PG z dnia 22 grudnia 2015 r.; opinia KIBR z dnia 28 grudnia 2015 r., http://www.sejm.gov.pl/Sejm8.nsf/druk.xsp?nr=75 (dostęp 03.12.2017 r.). 
strukcjom normatywnym. Opinia wskazuje na zupełnie hipotetyczne problemy interpretacyjne związane $\mathrm{z}$ prawidłowym odtworzeniem normy zawartej w art. $5^{66}$ oraz art. 8 ust. $2^{67}$ ustawy o podatku bankowym. W opinii Business Center Club elementy podatku nie spełniają wymogu dostatecznej określoności ${ }^{68}$.

Z punktu widzenia badanego problemu interesujący jest również fakt, że żadnej argumentacji w zakresie przepisów dostosowawczych nie sformułował Związek Banków Polskich (dalej: ZBP), jak to np. stało się w przypadku projektu ustawy o zmianie ustawy o podatku dochodowym od osób prawnych, ustawy o podatku dochodowym od osób fizycznych oraz niektórych innych ustaw z dnia 29 maja 2013 r., w którym ZBP wskazał m.in. na praktyczny problem związany z koniecznymi zmianami w systemie informatycznym banków oraz modyfikacjami w procedurach i kosztach obsługi rachunków przedsiębiorców oraz gromadzonych danych. Z związku z tym ZBP postulował wprowadzenie okresu vacatio legis dostosowanego do skali polskiego systemu bankowego, który pozwoli na prawidłowe przygotowanie się banków do wykonywania nowych obowiązków $^{69}$. Analogiczne stanowisko zostało zawarte przez ZBP w stosunku do projektu ustawy o zmianie ustawy o podatku dochodowym od osób prawnych, ustawy o podatku dochodowym od osób fizycznych oraz niektórych innych ustaw z dnia 19 grudnia 2013 r. ${ }^{70}$

66 W zakresie podstawy opodatkowania.

67 W zakresie deklaracji podatkowej, obliczania oraz wpłacania podatku.

68 Opinia BCC z dnia 21 grudnia 2015 r., s. 6, http://www.sejm.gov.pl/Sejm8.nsf/druk.xsp? documentId=854E93303B65AA73C1257F29004EBD1B (dostęp: 21.12.2017 r.). Komentarz do stanowiska BCC w tym zakresie pozostaje poza zakresem przedmiotowym opracowania.

69 Stanowisko ZBP do projektu ustawy o zmianie ustawy o podatku dochodowym od osób prawnych, ustawy o podatku dochodowym od osób fizycznych oraz niektórych innych ustaw (projekt z dnia 29 maja 2013 r.), s. 13, https://zbp.pl/public/repozytorium/ dla_bankow/rady_i_komitety/ekonomia_i_regulacje/podatki/ZBP_uwagi_nowelizacja_ CIT_PIT_06_2013.pdf (dostęp: 25.03.2018 r.).

70 Stanowisko ZBP do projektu ustawy o zmianie ustawy o podatku dochodowym od osób prawnych, ustawy o podatku dochodowym od osób fizycznych oraz niektórych innych ustaw (projekt z dnia 9 grudnia 2013 r.), s. 14, https://zbp.pl/public/repozytorium/ dla_bankow/newsletter/2014_styczen/EiR/ZBP_stanowisko_nowelizacja_PIT_CIT_12 _2013.pdf (dostęp: 17.02.2018 r.). 
Godny uwagi jest również fakt, że żaden zainteresowany podmiot, inaczej niż w przypadku omawianego wcześniej podatku od kopalin, nie zwrócił się również do Trybunału Konstytucyjnego w celu zbadania zgodności przepisów dostosowawczych. Warto zauważyć, że wniosek taki nie został skierowany w zakresie żadnego z przepisów ustawy.

Konfirmacji tezy o nieodpowiedniości przepisów dostosowawczych nie przyniosło również przeprowadzone przez autora badanie w tym zakresie. Co prawda większość respondentów będących przedstawicielami opodatkowanych grup nie zadeklarowała udziału w badaniu albo wprost odmówiła udziału, tym niemniej trzy spośród badanych podmiotów wprost stwierdziły, że żaden inny, dłuższy termin przepisów dostosowawczych nie miałby wpływu na dostosowanie działalności podatników do nowej rzeczywistości prawnej. Jeden z respondentów co prawda zadeklarował, że inny, dłuższy termin pozwoliłby na uniknięcie lub ograniczenie wzrostu produktów sprzedażowych, ale nie określił, dlaczego i jaki termin mógłby być w tym zakresie odpowiedni. Jeden z respondentów odnotował spadek oprocentowania depozytów w stosunku do okresu sprzed wejścia w życie ustawy o podatku od niektórych instytucji finansowych na poziomie $2 \%$ oraz spadek sprzedaży produktów bankowych na poziomie $30 \%$, niemniej uznał za indyferentny wpływ 14-dniowego terminu vacatio legis na zaistniałe zjawisko. Kolejny podmiot nie był obowiązany do zapłaty podatku ze względu na wysokość aktywów. Natomiast ani jeden z badanych podmiotów nie odnotował żadnych problemów praktycznych w związku z 14-dniowym okresem vacatio legis ${ }^{71}$.

Analiza wyników badania - co prawda przeprowadzona na niewielkiej grupie badawczej - skłania do wniosku, że dłuższy termin przepisów dostosowawczych prowadziłby wyłącznie do zaniechania poboru podatku w tym okresie.

${ }^{71} \mathrm{Z}$ wyjątkiem wzrostu ceny produktów sprzedażowych. 


\section{Ocena odpowiedniości terminu przepisów dostosowawczych podatku bankowego}

Pogląd Trybunału Konstytucyjnego wyrażony w wyroku z dnia 18 listopada 2014 r., K 23/12, został poddany krytyce, z czym nie można się nie zgodzić. Krytycznie należy ocenić samo twierdzenie, że krótkie vacatio legis ustawy podatkowej można „zbilansować” możliwością zapoznania się z projektowanymi rozwiązaniami w trakcie uchwalania projektu ustawy, która ostatecznego kształtu nabiera dopiero w ostatnim czytaniu ${ }^{72}$. Po drugie, także krytycznie należy ocenić argument Trybunału Konstytucyjnego sprowadzający się do twierdzenia, że „cel uświęca środki”, bowiem planowane korzyści (zapewnienie równowagi budżetowej) związane z 14-dniowym okresem vacatio legis nie mogą stać do materialnych gwarancji konstytucyjnych. Po trzecie, w orzecznictwie Trybunału zauważalna jest wyraźna niekonsekwencja pomiędzy krytykowanym wyrokiem a dotychczasowym orzecznictwem, z którego wynika konieczność zagwarantowania przez ustawodawcę adresatom unormowań prawnopodatkowych maksymalnej przewidywalności i obliczalności rozstrzygnięć podejmowanych wobec podatników przez organy skarbowe ${ }^{73}$, czemu służyć ma wymóg prawidłowej legislacji wskazujący, iż zmiany w systemie podatkowym na rok następny winny zostać ogłoszone co najmniej na miesiąc przed rozpoczęciem tego roku ${ }^{74}$.

W omawianej sprawie dotyczącej podatku od kopalin wnioskodawca wskazał doniosłe problemy praktyczne związane z wprowadzeniem podatku. Natomiast przeprowadzona analiza uwag zawartych w opiniach do projektu ustawy o podatku bankowym oraz zrealizowane przez autora badanie, w szczególności zaangażowanie się w badanie tylko nieznacznej części populacji należącej do grupy badawczej, zasadniczo świadczy o tym, że postawiona teza o rzekomej nieodpowiedniości terminu omawianej ustawy o podatku bankowym jawi się jako lobbystyczny mit, ma-

\footnotetext{
72 Projekt ustawy o podatku bankowym wpłynął do Sejmu w dniu 3 grudnia 2015 r., a uchwalony został w dniu 15 stycznia $2016 \mathrm{r}$.

73 Biuro Trybunału Konstytucyjnego, Proces prawotwórczy..., s. 30.

74 Wyrok TK z dnia 27 lutego 2002 r., K 47/01, LEX nr 52925.
} 
jący na celu wyłącznie próbę pozamerytorycznego zdyskredytowania nowego uregulowania, a nie rzeczową polemikę, z której wynikłoby np. to, iż ustawodawca nie wsłuchał się w zasługujący na uwagę głos opinii społecznej.

Biorąc pod uwagę przede wszystkim fakt, że pomiędzy publikacją projektu oraz wejściem w życie ustawy minęło ok. dwóch miesięcy, a w tym czasie nie pojawił się żaden sprecyzowany postulat dotyczący przepisów dostosowawczych omawianego uregulowania, nie sposób zgodzić się z tezą, termin wejścia tych przepisów w życie był zbyt krótki, bowiem inny termin w sytuacji podatników zobowiązanych do zapłaty i tak niczego by nie zmienił, tym bardziej że ustawodawca otworzył dla podatników „furtkę” podatkową w postaci m.in. możliwości pomniejszenia aktywów przez obligacje skarbowe znajdujące się w portfelu banków, z której podatnicy chętnie skorzystali ${ }^{75}$.

\section{Podsumowanie}

Problem odpowiedniości vacatio legis zasadniczo powinno odnieść się do zagadnienia związanego z możliwością pokierowania swoimi sprawami po ogłoszeniu nowych przepisów przez bezpośrednio zainteresowanych, tj. opodatkowane podmioty. Rozróżnić bowiem należy domniemanie wynikające z daty Dziennika Ustaw, w którym zostaje opublikowany akt normatywny, wskazujące, że adresaci normy prawnej zapoznali się z jej treścią, oraz rzeczywistą możliwość zapoznania się z nowym prawem ${ }^{76}$ i dostosowania do niego profilu własnej działalności gospodarczej.

75 Komisja Nadzoru Finansowego. Departament Bankowości Komercyjnej i Specjalistycznej oraz Instytucji Płatniczych, Syntetyczna..., s. 3.

76 Rozróżnić należy dwa pojęcia: „ogłoszenia” oraz „wejścia w życie” aktu prawnego. Przez „ogłoszenie” należy rozumieć czynność konwencjonalną polegającą na podaniu tego aktu do publicznej wiadomości w odpowiedniej formie, przewidzianej przez prawo (współcześnie - obwieszczenie w urzędowym dzienniku publikacyjnym), natomiast „wejście w życie” określane jest zasadniczo na dwa sposoby. Pierwszy sposób polega na wskazaniu terminu w ogólnym akcie normatywnym regulującym problematykę wejścia w życie aktów normatywnych, natomiast drugi sposób polega na każdorazowym wprowadzeniu terminu do uchwalanego aktu. T. Zalasiński, Zasada prawidłowej legislacji w poglądach Trybunału Konstytucyjnego, Warszawa 2008, s. 152-153. 
Chodzi tu przede wszystkim o możliwość adaptacji do zmienionej rzeczywistości prawnej, co w sposób oczywisty jest zróżnicowane od charakteru adresata oraz sytuacji, w jakiej on się znajduje. Zagadnienie to powinno zostać również odniesione do gałęzi prawa, którego dotyczy ingerencja ustawodawcy. Na szczególną ostrożność zasługuje prawo daninowe, co stanowi w szczególności wynik utrwalenia się linii orzeczniczej Trybunału Konstytucyjnego, z której wynika, że swoboda ustawodawcy w kształtowaniu materialnych treści prawa jest równoważona istnieniem po stronie ustawodawcy obowiązku szanowania proceduralnych aspektów zasady demokratycznego państwa prawnego, w szczególności zasad przyzwoitej legislacji, których konsekwencją jest wprowadzenie odpowiedniego okresu dostosowawczego, odpowiadającego zasadzie pewności prawa oraz zasadzie zaufania obywateli do państwa ${ }^{77}$. Ewolucja poglądów Trybunału Konstytucyjnego doprowadziła do utrwalenia stanowiska, zgodnie z którym nakaz stosowania odpowiedniego vacatio legis jest samodzielną zasadą prawa, mającą oparcie w wyżej wspomnianych zasadach konstytucyjnych ${ }^{78}$.

Odpowiednie dostosowanie vacatio legis ma służyć nie tylko formalnemu zapoznaniu się z nową regulacją, ale także pozostawić „odpowiednią” ilość czasu, aby adresat normy mógł dostosować swoje przedsięwzięcia do zmieniającego się stanu prawnego w celu uniknięcia pułapki, w wyniku której ingerencja w dotychczasową sytuację jednostki przyniesie jej skutki niezamierzone i nieodwracalne, a wręcz szkodliwe na płaszczyźnie życia gospodarczego, pomimo zachowania formalnych wymogów prawa regulujących problematykę wejścia w życie aktów normatywnych ${ }^{79}$.

Złożoność omawianej kwestii odpowiedniości wymiaru vacatio legis należy odnieść również do zwykłych okoliczności oraz okoliczności szczególnych, w których 14-dniowe vacatio legis staje się nieodpowiednie. W pierwszym wypadku wymiar vacatio legis ma charakter for-

\footnotetext{
77 I. Wróblewska, Zasada państwa prawnego w orzecznictwie Trybunału Konstytucyjnego RP, Toruń 2010, s. 142-144.

78 T. Zalasiński, Zasada..., s. 160.

79 Tamże.
} 
malny, w drugim - odpowiednie wydłużenie vacatio legis jest spowodowane m.in. wprowadzeniem nowych instytucji. W doktrynie przyjmuje się, że w tym przypadku okres vacatio legis powinien wynosić co najmniej kilka miesięcy, a w sytuacji, gdy zajdzie okoliczność wskazująca na konieczność „odpowiedniego” wydłużenia vacatio legis, jego długość powinna być ustalana indywidualnie w zależności od określonego stanu faktycznego $^{80}$.

Analiza przeprowadzonych badań nie doprowadziła jednak do wniosku, że w przypadku omawianej ustawy zaistniały okoliczności determinujące wprowadzenie innego, dłuższego terminu w stosunku do tego, który ustawodawca uznał za odpowiedni.

\section{Bibliografia:}

Dec P., Masiukiewicz P., Podatek bankowy, C.H. Beck, Warszawa 2013.

Etel L., Liszewski G., Podatki majqtkowe w Polsce - wybrane problemy, Kancelaria Sejmu. Biuro Studiów i Ekspertyz. Wydział Studiów Budżetowych, raport nr 209, wrzesień 2002.

Fojcik-Mastalska E., Mastalski R., Prawo finansowe, Lex a Wolters Kluwer business, Warszawa 2013.

Gomułowicz A., Mączyński D., Podatki i prawo podatkowe, Wolters Kluwer, Warszawa 2016.

Jaskiernia J., Zasady demokratycznego państwa prawnego w sejmowym postępowaniu ustawodawczym, Wydawnictw Sejmowe, Warszawa 1999.

Kwietko-Bębnowski M., Ordynacja podatkowa. 366 wyjaśnień i interpretacji, Lex a Wolters Kluwer business, Warszawa 2013.

Marcinkowska M., Dodatkowe opłaty i podatki od banków - potrzeby praktyki i dylematy teorii finansów, http://kbd.projektekf.pl/sites/default/files/ materialy_prasowe/podatek\%20bankowy_Marcinkowska.pdf

Mastalski R., Stosowanie prawa podatkowego, Oficyna a Wolters Kluwer business, Warszawa 2008.

Mastalski R., Tworzenie prawa podatkowego a jego stosowanie, Wolters Kluwer, Warszawa 2016.

Wolański R., System podatkowy w Polsce, Wolters Kluwer, Warszawa 2016.

80 Tamże, s. 164. 
Vacatio legis ustawy o podatku od niektórych instytucji...

Wróblewska I., Zasada państwa prawnego w orzecznictwie Trybunału Konstytucyjnego RP, TNOiK, Toruń 2010.

Zalasiński T., Zasada prawidłowej legislacji w poglądach Trybunału Konstytucyjnego, Wydawnictwo Sejmowe, Warszawa 2008. 